\title{
Erratum to: Successful written subject-verb agreement: an online analysis of the procedure used by students in Grades 3, 5 and 12
}

\author{
Denis Alamargot • Lisa Flouret • Denis Larocque • \\ Gilles Caporossi • Virginie Pontart • \\ Carmen Paduraru • Pauline Morisset • Michel Fayol
}

Published online: 20 September 2014

(C) Springer Science+Business Media Dordrecht 2014

\section{Erratum to: Read Writ \\ DOI 10.1007/s11145-014-9525-0}

The running head of the paper "L. Flouret et al." has been wrongly identified in the original published article. The correct representation of the running head title is "D. Alamargot et al."

The online version of the original article can be found under doi:10.1007/s11145-014-9525-0.

D. Alamargot · L. Flouret · V. Pontart

CHArt Laboratory, University of Paris 8, Paris, France

D. Alamargot $(\bowtie) \cdot$ P. Morisset

ESPE de 1'Académie de Créteil, University of Paris-Est Créteil (UPEC), Site de Bonneuil, rue Jean Macé, 94861 Bonneuil sur Marne Cedex, Paris, France

e-mail: Denis.Alamargot@u-pec.fr

D. Larocque · G. Caporossi

HEC Montreal, Montreal, QC, Canada

G. Caporossi

GERAD Laboratory, University of Montreal, Montreal, QC, Canada

C. Paduraru

CeRCA-CNRS Laboratory, University of Poitiers, Poitiers, France

M. Fayol

LAPSCO-CNRS Laboratory, Blaise Pascal University, Clermont-Ferrand, France 